\title{
IFRS ADOPTION AND FINANCIAL REPORTING QUALITY: A REVIEW OF EVIDENCES IN DIFFERENT JURISDICTIONS
}

\author{
Habeeb Mohamed Nijam ${ }^{1, a^{*}}$, Athambawa Jahfer ${ }^{2, b}$ \\ ${ }^{1,2}$ Department of Accountancy and Finance, Faculty of Management and Commerce, South \\ Eastern University of Sri Lanka, Oluvil, Sri Lanka. \\ a Corresponding Email: nijamhm@seu.ac.lk \\ ${ }^{\mathrm{b}}$ Corresponding Email: jahfer@seu.ac.lk
}

\begin{abstract}
Keywords: IFRS, Review, Accounting, Quality, Standards, Adoption, Impact, Evaluation, Convergence, Harmonization,
\end{abstract}

\begin{abstract}
Conventional and commonly held wisdom with respect to the adoption of International Financial Reporting Standards (IFRS) is that they lead to improved financial reporting quality and comparability and thereby favorable economic consequences. There are however contradicting evidences disproving this conventional wisdom or rejecting its gross generalization over the entire jurisdictions harmonizing on IFRS. Driven by this fact, quests for knowledge about the dynamics and contexts that lead to differential effects of IFRS get momentum. In an attempt to explore the insight into the effects of international accounting harmonization by way of IFRS adoption, this paper reviews selected literatures on consequences of IFRS adoption. This review discusses some empirical evidences that have been reported in various countries that include Europe, USA, United Kingdom, Germany, Spain, Norway, Greece, Poland, Belgian, France, Italy, Turkey, United Arab Emirates (UAE), Kuwait, Jordan, China, Malaysia, Australia, Hong Kong, New Zealand, Kenya and Nigeria. Our review focuses on the aspects of value relevance, disclosure quality, cost of capital, earning management and financial statement impact due to the IFRS adoption. This review reveals that economic consequences of IFRS adoption significantly differ across jurisdictions though being its impact reported to be positive in majority of cases. There are also notable number of studies that report indifferent and or negative effects of IFRS adoption. When IFRS studies report mixed evidence with respect to value relevance of book value of equity and earing, book value of equity supersedes the earning parameters. IFRS are found to supersede many other domestic financial reporting standards in terms of volume and quality of disclosures in financial statements. This review also obtains that IFRS' impact on the reduction of cost of capital depends on financial reporting incentives, law enforcement, types of legal systems and various other country and capital market specific characteristics. Further, though there are some evidences to the contrary, the quality of earnings reported under IFRS has been established to be superior to that under other local standards.
\end{abstract}

\section{Introduction}

Different accounting standards may lead to differences in financial reporting and its quality even with same set of accounting data. Thus, when accounting regimes change it significantly affects the financial position and performance being reported. International Financial Reporting Standards (IFRS) are increasingly being adopted by countries around the globe as it is commonly believed that they improve financial reporting quality and comparability. Lee et al. [1] claim that views among academics and practitioners with regard to the potential economic consequences driven by IFRS adoption remain unconsented and divided and empirical evidence are sought to verdict on this dispute. IFRS adoption experience is different across different countries due to diversifies in underlying economic characteristic, quality of accounting standards prior to the adoption of IFRS, enforcement etc. However, upon the review of the literatures that report economic consequences of IFRS adoption, one can find that the economic consequences of IFRS are evidenced, in majority of cases, to be positive and in some cases negative and indifferent as compared to the local accounting 
standards prior to the adoption of IFRS in such countries. Thus, there are research finding challenging the common belief that IFRS enhance financial reporting quality. Researches that sought to investigate the economic consequences of IFRS adoption have compared inter alia the value relevance of accounting information, earning management and forecast precisions of financial statement reported under IFRS with that under the domestic accounting standards existed prior to the adoption of IFRS.

In an attempt to explore the insight into the effects of international accounting harmonization by way of IFRS adoption, this paper reviews selected literatures on the consequences of IFRS adoption. Our review focuses on the aspects of value relevance, disclosure quality, cost of capital, earning management and financial statement impact.

\section{IFRS Adoption and Value Relevance}

Financial reporting quality has often been judged by the power of information in financial statement in explaining firms' value. IFRS literature consists of many papers documenting the influence of IFRS on the effects of value relevance of accounting information. The effect of IFRS on value relevance of accounting information is different across jurisdictions and seems to depend on characteristics of the accounting information concerned and the nature of the economy in which sample firms operate. Iatridis [2] studied on the impacts of IFRS adoption in the UK and found that the implementations of IFRS generally strengthen accounting quality and lead to more value relevant accounting information. Tsoligkas and Tsalavoutas [3] study the value relevance of capitalized R\&D expenditure after the implementation of IFRS in the UK. Their results indicate that the capitalized R\&D expenditure is positively value relevant during the first three years of the mandatory implementation of IFRS. This evidence was not however found during the pre-IFRS period under UK GAAP. In addition, they also find that the expensed portion of R\&D expenditure is significantly and negatively value relevant. Their findings assert the view that accounting information disclosed under IFRS better represent firms' economic fundamentals.

Jermakowicz et al. [4] performed regression analysis to measure the value relevance where predictability of market value of DAX-30 companies in Germany using book values of earnings and equity. The study employed the data of the period from 1995 to 2004 . Using 265 observations, they report that adopting IFRS or US GAAP or cross-listing on the New York Stock Exchange significantly increases the value relevance of earnings of DAX-30 companies relative to their market prices. Callao et al. [5] study the effects caused by the introduction of the new standards on comparability and relevance of financial reporting in Spain focusing on IBEX-35 companies and find that comparability of financial statement is adversely affected if both IFRS and local accounting standards are concurrently used in a jurisdiction and therefore suggest adoption of international accounting standards. They also hold that despite the value relevance of accounting information has not been significantly improved in the short run with adoption of IFRS, it is expected to improve in the medium and long run.

Beisland and Knivsfla [6] investigate the impact of IFRS adoption in Norway and report that expanded fair value accounting under IFRS increases the value relevance of book values and decreases the value relevance of earnings. They also find that the improved matching of intangible asset expenditures with the future economic benefits of such intangible assets increases the persistence and value relevance of earnings relative to book values. This conclusion has been related to the distinction between Norwegian Generally Accepted Accounting Principles (NGAAP) and IFRS. They claim that IFRS are balance sheet-oriented and emphasize measurement at fair value whereas NGAAP, by contrast, are earnings-oriented and focus on historical cost. Further, IFRS also differ from NGAAP by recognizing more intangible assets. Overall, IFRS are thus less conservative than NGAAP. Negakis [7] examines the effects of the introduction of the IFRS on the explanatory power of earnings for stock returns in Greece using variants of the Easton and Harris 
model and controls for asymmetries in the information content of earnings and losses. The findings show that the IFRS had several effects on the value relevance of earnings particularly the available information content related to both earnings and earning changes decreased after the introduction of the IFRS. The reduction in the information content of earnings for returns (or the information content of book values of equity for stock prices) could be attributed to the IFRS and, in particular, to the introduction of the fair value principle. Moreover, even after controlling for the existence of asymmetries, the findings of reduced information content of earnings and earning changes for stock returns persist. However, Karampinis and Hevas [8] evaluated the impact of the mandatory adoption of IFRS on the value relevance of earnings and book values with data from the Athens Stock Exchange that covered a time span of two years before and after the mandatory adoption of IFRS. They hypothesized that earnings and book value to become more value relevant as IFRS adoption promotes fair value accounting and weakens the link between taxation and accounting rules. They find that the adoption of IFRS positively influenced the value relevance of consolidated net income and book value though it had no effect on their unconsolidated figures and that consolidated accounting numbers are more value relevant than unconsolidated numbers in both periods. The study observed unexpected superiority of consolidated accounting numbers is more noticeable after IFRS adoption. They also hold that disaggregating net income improves the explanatory power of the earnings book value capitalization (EBVC) model whereas the incremental explanatory power of both net income and financial income decreases. Taking into account the total impact of IFRS adoption due to the actual increase in the overall explanatory power of the models, they upheld that mandating IFRS may prove beneficial even in an unfavorable context.

Iatridis and Rouvolis [9] also provided that IFRS adoption leads to more value relevant accounting measures in Greece Stock Exchange for 254 firms. Ballas et al. [10] examined the relevance of IFRS in Greece by adopting a mixed methodology relying primarily on secondary sources such as the relevant legislation, published annual reports and other reports on the effects of the application of IFRS by Greek firms as well as the results of a postal survey addressed to the finance managers of the top 100 Greek firms. They however found that although the Greek environment was not appropriate for IFRS application, participants in the survey believe that their adoption improved the quality of financial reporting. The introduction of IFRS increased the reliability, transparency and comparability of the financial statements. Karampinis and Hevas [11] investigate the effects of IFRS adoption in the contexts of value relevance and conditional conservatism in Greece and observe only minor improvements with respect to selected properties of income. Study of Papadatos and Bellas [12] in Greece found that impact of IFRS adoption was not indifferent. Rather, relation between mandatory implementation of IFRS and value relevance of accounting information are significantly subject to both firm size and fixed assets factors. Dobija and Klimczak [13] found, with the value relevance of accounting information in Polish market, that adoption of accounting standards did not impact market efficiency and value relevance at a significant level. Kirkulak and Balsari [14] study the impact of accounting data on predicting the market value of equity and stock returns in Turkey which has adopted IFRS. They reveal that book value and earnings information are value relevant both under historical cost-based accounting and inflationadjusted accounting. Türel [15] compared the value relevance of accounting information for the periods 2001-2002 and 2005-2006 in Turkey and report that the value relevance of earnings and book value of equity has increased after adopting IFRS for the given period. Kargin [16] who investigated the value relevance of accounting information in pre- and post-financial periods of IFRS application for Turkish listed firms from 1998 to 2011 found that market value is related to book value and earnings per share when the Ohlson model (1995) ${ }^{1}$ [17] was applied and overall book value was also found to have value relevant in determining market value or stock prices. The

\footnotetext{
${ }^{1}$ Ohlson's value relevance model is basically stated as $M V_{i t}=\alpha+\beta_{1} B V_{i t}+\beta_{2} E P S_{i t}+\varepsilon_{i t .}$. Where, $\mathrm{MV}_{i t}$ is the market value of firm $i$ at time $t, B V i t$ is the book value of equity of firm $i$ at year $t, E P S_{i t}$ is earnings per share of firm $i$ at the time $t$ and $\varepsilon_{i t}$ is error term.
} 
results also showed that value relevance of accounting information has improved in the post-IFRS period (2005-2011) considering book values while improvements have not been observed in value relevance of earning.

$\mathrm{Ji}$ and $\mathrm{Lu} \mathrm{[18]} \mathrm{examined} \mathrm{the} \mathrm{value} \mathrm{relevance} \mathrm{of} \mathrm{intangible} \mathrm{assets,} \mathrm{including} \mathrm{goodwill} \mathrm{and} \mathrm{other}$ types of intangibles in the pre- and post-adoption periods of IFRS in Australia. They mainly focused whether the value relevance of reported intangible assets is associated with their value reliability and whether the adoption of IFRS improves the value relevance of intangible assets and alters the relationship between value relevance and reliability. They employed both price and return models based on Ohlosn model for 6,650 firm-year sample observations for Australian-listed firms with capitalized intangibles from 2001 to 2009. They found that capitalized intangible assets are value relevant in Australia, in both the pre- and post-adoption of IFRS periods and value relevance is higher in firms with more reliable information on intangible assets. They also report that though the positive relationship between the value relevance and the reliability of intangibles has remained unchanged in the post-adoption period the value relevance of intangibles has declined in the postadoption period of IFRS. Khanagha [19] studied the value relevance impact of IFRS implementation in United Arab Emirates (UAE) comparing pre- and post-periods data and showed that accounting information is value relevant in UAE stock market in general but claimed that the value relevance of accounting data decreased with IFRS application. The study also revealed that cash flows' incremental information content increased in the post-IFRS period. Elshamy et al. [20] examines the value relevance of unrealized gains and losses recognized under IFRS (that is, IAS 39) with companies listed on the Kuwait Stock Exchange primarily using Ohlson's [17] valuation model. They find that unrealized gains and losses recognized under IFRS are value relevant and thus explaining stock prices of investment companies in Kuwait and that inclusion of these amounts in the income increases the incremental explanatory power of earnings. They also report that as found in cross-sectional regression analysis that: net income and book values jointly and individually are positively and significantly related to stock prices; the incremental information content of net income is greater than that of book values; (3) the inclusion of unrealized gain in income increases the explanatory power of the model; (4) the incremental information content of net income before unrealized gains and losses is lower than that of book value. Nijam [21] investigated the impact of IFRS adoption on value relevance of accounting information using the sample of 188 firms and 935 firm-year observations which nearly constitute to all firms listed in Colombo Stock Exchange (CSE) except those not having at least two annual reports before and after the year 2012 and those having extreme and missing values. The study employed Ohlson [17] price regression model. The pre-IFRS period was designated as 2010 through to 2011 and the postIFRS period was 2012 through to 2014. The study found that the accounting information published by firms in CSE continue to be value relevant. Book Value of Equity per Share (BVEPS) and Earning per Share (EPS) are also value relevant before and after the adoption of IFRS. Though the overall predictive power of value relevance model improved in the years followed by the adoption of IFRS, value relevance of BVEPS has declined in the years after IFRS adoption.

There are several studies that investigate the comparative value relevance of accounting information, following the implementation of IFRS in the context of the Chinese stock markets. Chinese stock markets, A-shares are issued for domestic investors whereas B-shares are foreign investors' shares. Firms with B-shares must produce both IAS-GAAP and China-GAAP financial reports. Also, the firms issuing A\&B-shares are required to prepare two sets of financial statements: one based on China-GAAP and the other based on IAS-GAAP. Bao and Chow [22] examine only B-share market for the period 1993-1996 and compared the value relevance created under IFRS and CAS and concluded that IFRS-based earnings and book values have greater relevance than those based under CAS. Eccher and Healy [23] applies the returns model to examine the value relevance and the relative value relevance of CAS- and IFRS-based accounting measures in both the A- and B-share markets during the period 1992-1997. They report that both CAS- and IFRS-based 
measures are value relevant in the A- and B-share markets. However, in the A-share market, CAS earnings record a higher relation with stock returns than IFRS earnings, while in the B-share market neither is better than the other. That is, CAS- and IFRS-based earnings have a similar association with stock returns. $\mathrm{Hu}$ [24] finds that CAS-based earnings and book values of B-share companies listed in the SHSE are more value relevant than those based on IFRS. Sami and Zhou [25] examine whether CAS-based measures are value relevant in the A-share market, and whether IFRS-based measures are value relevant in the B-share market. They find that accounting numbers are value relevant in pricing A- and B-shares, but are more value relevant in the B-share market ( in which the IFRS rule the financial reporting) than the A-share market. The problem with this study is that it treats the two markets as segmented thereby indicating that this is true for A-share only companies and B-share only companies, it may not hold for A- and B-share companies. Liu and Liu [26] repeated Sami and Zhou [24] investigating the value relevance of accounting information reported under China GAAP (CAS), IFRS and Hong Kong GAAP. They investigate CAS-based measures in the A-share market, IFRS-based measures in the B-share market, and Hong Kong (HK) GAAPbased measures in the H-share market for the period 1999-2003 and reveal that accounting information is value relevant in each market segment while IFRS-/HK-GAAP-based accounting information is more value relevant in the $\mathrm{B}$ - and $\mathrm{H}$-share markets, respectively than CAS-based measures in the A-share market. Chalmers at al. [27] aimed to investigate whether the accounting reform in China has improved the relevance of China's accounting information. It seeks to investigate the relationship between earnings and book value of equity to share returns before and after the introduction of the Accounting System for Business Enterprises (ASBE) in 2001 for Aand A\&B-share firms. Studies focused on B-share. The pre-ASBE period is designated as 1997 to 2000 , and the post-ASBE period is designated as 2002 to 2004 . The study employed the return regression model for all firms listed on the Chinese stock market and found that accounting information better explains share returns for both A-share firms and A\&B-share firms in the postASBE period. They also demonstrate that the book value of equity for A\&B-share firms is incrementally value relevant to that of A-share firms in the post-ASBE period.

Chamisa et al. [28] studied using data for 86 Chinese listed companies which issued both A- and Bshares and revealed that for both the A-share and B-share markets, both Chinese Accounting Standards (CAS)-based and IFRS-based accounting information are value relevant, but IFRS-based information is more value relevant than the CAS-based information. They claim that this is the first to investigate the relative value relevance of CAS- and IFRS-based accounting measures in both the A- and B-share markets covering all the three distinct periods when CAS was progressively harmonized with IFRS. They also noted that the magnitude of the differences between the explanatory powers of the CAS- and IFRS-based accounting information narrowed significantly in the 2001-2004 period in both the A-share and B-share markets. Reported findings were claimed to be robust to the deflator used and the stock exchange on which the companies are listed. The study employed the price model and J-test in performance of this analysis.

Kadri et al. [29] examined the value relevance of book value and earnings and the relationship between earnings and operating cash flow of two different financial reporting regimes in Malaysia. They employ market and nonmarket valuation approaches for that purpose. Under market valuation approach on pool sample book values and earnings are value relevant and the change in financial reporting regime affects significantly the value relevance of book value and but not earnings. While book value and earnings are value relevant during the MASB period, only book value is value relevance during the FRS which are equivalent to IFRS. On the other hand, under the non-market valuation approach, they relate earnings and operating cash flow and find that the change in financial reporting regime has no significant effect on the relationship between earnings and operating cash flow. The result of market valuation approach reveals that the introduction of FRS which reflects IFRS improved the position of book value in equity valuation. The result of nonmarket valuation model records that the degree of relationship between earnings and operating cash 
flow persists as long as operating cash flow include cash and cash equivalent components whereas earnings comprise of cash and accruals components. Van der Meulen et al. [30] examine the differences of reported earning quality between US GAAP and IFRS based earnings in the contexts of value relevance and timeliness. They find that US GAAP and IFRS only differ with regard to the predictive ability as US GAAP outperforms IFRS in given controlling differences. However, they find no significant and consistent differences for the value relevance attribute. Verleun et al. [31] investigate technology and non-technology firms in order to assess the impact made by the Sarbanes-Oxley (SOX) Act on the quality of financial statements in U.S.A. They report that the enactment of SOX has had a positive effect on accounting quality where the value relevance of accounting information has also increased after the enactment of SOX Act.

Umoren and Enang [32] evaluated the impact of IFRS adoption on value relevance of financial information in the financial statements of commercial banks in Nigeria using twelve listed banks through the periods of 2010 and 2011 (pre-adoption period) and 2012 and 2013 (post-adoption). The result reveals that the equity value and earnings are more relevant to share prices under IFRS than under the previous Nigerian SAS. They also indicate that earnings per share is incrementally value relevant during post-IFRS period while book value of equity per share is incrementally less value relevant during the post-IFRS period

\section{IFRS Adoption and Disclosure Quality}

IFRS adoption has been investigated in relation to the improvement in quality of discloser provided in financial statements. It is generally viewed that IFRS impose relatively more disclosure requirements in the course of improving financial reporting quality and addressing information asymmetry. The volume of information, their decision usefulness and value relevance have been under focus when exploring the quality of disclosures to financial statements under IFRS. Daske and Gu"nther [33] evaluated disclosure the quality of the financial statements of three European countries such as Austrian, German and Swiss where firms have already adopted IFRS or US GAAP. They employed disclosure quality scores obtained upon a detailed analysis of annual reports. They report that perceived disclosure quality has significantly increased for companies reporting based on internationally recognized accounting standards, IFRS in particular. This result is observed not only with voluntary adopters but also but also for firms which adopted such standards mandatorily in response to stock market requirements. Tsalavoutas and Dionysiou [34] measured the level of compliance with all IFRS mandatory disclosure requirements for a sample of firms in Athens Stock Exchange (ASE), Greece for explaining whether the compliance scores (i.e. the mandatory disclosure levels) are value relevant and whether the value relevance of accounting numbers differs across high- and low-compliance/disclosure companies. The paper revealed that the levels of mandatory disclosures are value relevant and also the valuation coefficient of net income of high-compliance companies is significantly higher than that of low compliance companies.

Mardini et al. [35] studied a sample of 109 Jordanian companies to assess the segmental information provided by the sample companies with disclosure index checklist which collected information about: the number of segments reported; the number and type of segmental items published; the geographic segment definitions (areas) used; and the identity of the chief operating decision maker. The results suggest that segmental disclosures under IFRS 8 have increased compared to the information published under IAS 14R. Bova and Pereira [36] investigates whether IFRS compliance enhances a firm's information environment in Kenya. They claim that IFRS being a higher-quality accounting standards leads to higher-quality financial reporting and transparency and further argue that IFRS limits managerial discretion and enforces greater disclosure requirements as compared to domestic GAAP. The study finds that Compliance to IFRS is higher among public, rather than private, firms and relates to higher share turnover. The findings imply that ensuring IFRS compliance in Kenya would create economic incentives and capital market benefits. Macías and Muiño [37] investigated accounting systems of countries in Europe where 
some countries had adopted IFRS at a full scale while some others adopted partially. Results revealed that quality of accounting information improves with the full scale implementation of IFRS. They held further that requiring the use of local standards in the preparation of legal entity financial statements provides lower level of accounting quality both prior to and after IFRS adoption. It is however noteworthy Macías and Muiño [37] hold that firms in these countries have adopted IFRS mostly for complying with regulatory requirements and rather for satisfying investors' and creditors' needs.

\section{IFRS adoption and Cost of Capital}

Cost of equity capital is considered important in corporate finance and in making investment decisions and proponents of IFRS forecast that IFRS adoption leads to reduction of cost of capital [1]. Daske et al. [38] who studied the economic consequences of mandatory IFRS adoption with sample of firms across 26 countries covering four years period from 2001 to 2005 found that IFRS adoption tend to be associated with positive economic consequences for cost of capital. It was also revealed that these capital market effects are most evident in the cases of voluntary adopters, both in the year when they switch and again later, when IFRS applications become mandatory. They caution that the initial impact is likely to be attributed to self-selection and that the mandatory impact will be subject to such omitted variables as concurrent improvements to securities laws, regulatory enforcement, firm governance, and reporting incentives. Lee et al. [1] find, across a sample of 17 European countries, that the cost of capital only reduced in countries with high reporting incentives and enforcement. They find mixed evidence of reduction of cost of equity capital from the pre- to post-IFRS adoption periods when countries are having low financial reporting incentives and enforcement. They, in contrast, report a significant reduction in the cost of equity capital with respect to countries that are having higher financial reporting incentives and enforcement.

Han and He [39] compared the cost of equity of foreign firms during the IFRS reporting period (2007-2009) and the US GAAP reconciliation period (2004-2006) and found that the cost of equity in foreign firms is higher during the IFRS reporting period than the US GAAP reconciliation period. Further, foreign firms recorded a constantly higher cost of equity than that of matched US firms in both period. They also found that the change in cost of equity of foreign firms is also influenced by the use of IFRS in the home country of foreign firms evaluated. Lambertides and Mazouz [40] examined the impact of mandatory IFRS adoption on the informational efficiency, market stability, and price adjustment of underlying stocks in Europe. They studied 1,187 stocks from 20 European countries and report that the effects of IFRS adoption on the equity cost of capital are varied in response to the country-specific characteristics. They specifically concluded that the IFRS adoption is more likely to increase /decrease the betas of stocks that are listed in the common /civil law countries.

\section{IFRS Adoption and Earning Management}

Goncharov and Zimmermann [41] examine and compared the differences in the degree of earnings management in consolidated accounts of German companies prepared under three different accounting standards namely German GAAP, IAS and US GAAP. They report that the level of earnings management for firms that report their results under US GAAP is significantly lower while it is roughly equal under German GAAP and IAS. They hence conclude that the different accounting choices permitted in different accounting standards influence the level of earnings management. Barth et al. [42] find that application of IFRS leads to higher accounting quality. They study entities from 21 different countries applying IAS between 1994 and 2003 and report that there is less evidence of earnings management, more timely loss recognition and more value relevance of accounting information for their sample firms than for a matched sample of firms adopting non-US domestic GAAP. Jeanjean and Stolowy [43] examine the effect of the mandatory 
introduction of IFRS on earnings management in Australia, France and the UK and conclude that earnings management did not reduce after the introduction of IFRS. Rather, it increased in France. This paper claims that accounting standards play only a limited role in determining reporting quality. Management incentives and national institutional factors play more important roles in reporting quality. Doukakis [44] analyzed whether the adoption of IFRS materially affects the persistence, as well as the explanatory power of earnings and earnings components of two years before and two years after the adoption of IFRS in Greece and confirmed that disaggregating reported earnings into operating income, non-operating income and extraordinary charge and credit, captures differences in the information content of the underlying events thereby earnings disaggregation can be used to improve prediction of future profitability. The results reveal that IFRS measurement and reporting guidelines do not appear to improve the persistence of earnings and earnings components.

Cheong et al. [45] investigated whether financial analysts' forecast accuracy differs between the pre- and post-adoption of IFRS in the Asia-Pacific region, namely, for the countries of Australia, Hong Kong and New Zealand with the attention paid on whether the treatment of intangibles capitalized in the post-IFRS period have positively aided analysts in forecasting future earnings of a firm. They employed panel data analysis over a period from 2001 to 2008 and found that intangibles capitalized under the new recognition and measurement rules of IFRS are negatively associated with analysts' earnings forecast errors suggesting that the adoption of IFRS may indeed provide more value-relevant information in financial statements for the users of financial reports. The results were said to be robust to several model specifications across each of the countries. Chalmers et al. [46] study the relationship between the accuracy and dispersion of analysts' earnings forecasts and aggregated reported intangibles. They report that negative correlation between the two becomes stronger after IFRS adoption, confirming that accounting information under IFRS leads to more useful information. This works better particularly in relation to reported goodwill since IFRS employs an impairment approach on goodwill valuation while the former Australian GAAP amortizes the goodwill on straight-line basis. They claim that the impairment approach is more accurate method to value goodwill and IFRS thus makes the information about intangibles more value relevant enabling analysts to forecast earnings more precisely. Ismail et al. [47] investigated the differences in earnings quality of Malaysian companies after the adoption of IFRS-based accounting standards. The study tests specifically whether the level of earnings management is significantly lower after the adoption of IFRS, and reported earnings is more value relevant during the IFRS based accounting standards. Employing a sample of 4,010 observations over a three-year period before and a three-year period after the adoption of the new set of accounting standards, they found that IFRS adoption is associated with higher quality of reported earnings. It is also revealed that earnings reported during the period after the adoption of IFRS is associated with lower earnings management and higher value relevant. Aubert and Grudnitski [48] examined the change in the earnings manipulation during pre- and post-IFRS adoption periods using a sample of 15,034 firm-year observations from 20 European countries and found that the magnitude of the proxy for earnings manipulation declined with IFRS adoption indicating that a uniform financial reporting regime contributed to uncover the use of temporary activities to manipulate earnings. They claim that their finding validates the achievement of the goal of the European Commission through the adoption of a common set of high quality reporting standards.

\section{IFRS Adoption and Financial Statement Impact}

Hung and Subramanyam [49] investigates the financial statement impact due to the adopting IAS during the period from 1998 to 2002 in Germany by evaluating the financial statement effects by direct comparison of financial statements prepared under both IAS and HGB which are German GAAP. The results of analysis indicated that the adoption of IAS culminated in significant changes to deferred taxes, pensions, property, plant and equipment, and provisions for loss. Total assets, book value of equity and the variations in book value and net income are also found to be 
significantly larger under IAS than under HGB. Their examination on value relevance impact caused by IAS adoption found no evidence for that IAS improves value relevance of book value or net income. They also reported that there is weak evidence for that IAS income has incorporated bad news into income in a more timely manner than German GAAP.

Jermakowicz [50] examined the impact of IFRS adoption on BEL- 20 firms in Belgian. They employed questionnaire responded by Belgian companies and reported that implementing IFRS will dramatically change the way these companies design and handle both their internal and external reporting activities and will increase the comparability of consolidated accounts as well as the levels of transparency for many companies. They also analyzed the impact of three companies that were early adopters of IFRS in 2003 and finds that transition from Belgian GAAP to IFRS resulted in a significant impact on the companies' reported equity, as well as net income. Cordazzo [51], studies the nature and the size of the accounting differences between Italian accounting principles and IFRS. The investigation identifies and quantified the total and individual differences between Italian GAAP and IFRS in the reconciliations of net income and equity of companies listed on Borsa Italiana. The study finds that there exists a more relevant total impact of such a transition on net income than equity. The analysis of individual adjustments indicates a greater differences between Italian GAAP and IFRS in the accounting treatment of intangible assets, income taxes, and business combinations with reference to both net income and equity. The study concludes considering the overall facts that IFRS transition has produced significant effects on Italian accounting results. Bayerlein and Al Farooque [52] investigated the influence of the mandatory IFRS adoption in Australia (AUS), Hong Kong (HK) and the UK on deferred taxation (DT) and goodwill (GW) accounting practices as well as the within and between country harmonization of accounting practices is investigated through an event type study. These investigations are conducted using a McNemar test with Bowker extension as well as the Split C-Index with a newly developed bootstrapping significance testing methodology. This study reported that the mandatory IFRS adoption in the countries under analysis is linked to a significant harmonization of DT and GW accounting practices between AUS, HK and the UK and the increase of adequate accounting policy information in the financial reporting documents of UK firms over the period of this study is identified as an important harmonization accelerator.

Stent et al. [53] investigates the effects of NZ IFRS on the financial statements and ratios of firsttime adopters of NZ IFRS for a stratified random sample of 56 listed companies where 16 of were early adopters and 40 waited until adoption of NZ IFRS became mandatory. They report that 87 per cent of firms are affected by NZ IFRS and for most firms the impact of NZ IFRS is small. They also reveal that the impact can be large for some entities and the impact has considerable effects on common financial ratios. Bao et al. [54] examined the effect of the differences pertaining to reporting of inventory, property plant and equipment, intangible assets, and development costs between companies adopting IFRS and US Generally Accepted Accounting Principles (US GAAP). They showed that IFRS-country firms have a significantly higher current ratio, a significantly lower asset turnover ratio, and a significantly lower debt-to-asset ratio. Fifield et al. [55] examined the nature of the Income Statement and Net Equity IFRS adjustments for a sample of companies from the UK, Ireland and Italy following the introduction of IFRS and report that for all three countries under evaluation the profit reported under IFRS was greater than that reported under previous national GAAP. They also find that the IFRS also significantly affected on net worth. UK and Italian companies recorded an increase in equity after the adoption of IFRS while the Irish firms in the sample experienced a decrease. Their analysis showed that the impact of IFRS on profit and net worth was principally due to the application of few core standards which include IFRS 2, IFRS 3, IFRS 5, IAS 10, IAS 12, IAS 16, IAS 17, IAS 19, IAS 38 and IAS 39. Iatridis and Dalla [56] explored the effects of adopting IFRS on company financial position and performance the financial statements of Greek listed companies focusing on major Greek industrial sectors. The study finds that IFRS implementation has positively influenced the profitability of most industrial sectors while 
liquidity measures for a number of industrial sectors and stock market constituents moved negatively followed by the adoption of IFRS adoption. An increase in leverage is evident among the sample stock market indices and industrial sectors. This finding also exists among firms of large size and high financing needs.

\section{Discussion and Conclusion}

This review of empirical evidences from many countries reveals that economic consequences of IFRS adoption significantly differ across jurisdictions though being its impact reported to be positive in majority of cases. There are also notable number of studies that report indifferent and negative effects of IFRS adoption. IFRS effects are determined by comparing the parameters concerned between pre and post IFRS regimes in given jurisdiction/s or by comparing IFRS jurisdictions with similar non IFRS jurisdictions. It is found that earnings per share, book value of equity, research and development expenditure, goodwill, other capitalized intangible assets and unrealized gain are some of the key accounting information that have been used for testing relative value relevance or incremental value relevance caused by IFRS adoption. It is observed that conclusions in different jurisdictions with respect to the effect of IFRS on value relevance of accounting information are relatively more divided. Conclusions of majority of studies support that IFRS adoption increases the information content of accounting information and thus incrementally relating to the share price and or return. There are yet reasonable number of studies that do not find any improvements in value relevance of accounting information and or report reduction in value relevance after IFRS adoption. These unsupported evidences have often been argued in the context of increased emphasis of IFRS on fair values, concurrent use of domestic accounting standards, the higher quality of domestic standards that were in force prior to the IFRS adoption, law enforcement and the nature of capital markets in the jurisdictions concerned. It is also found that when IFRS studies report mixed evidence with respect to value relevance of book value of equity and earing, book value of equity supersedes the earning parameters. This may be attributed to the argument that IFRS is more balance sheet focused. Further, the value relevance of IFRS based consolidated net income and book value are more relevant than the unconsolidated figures. It is also observed that the impact of voluntary adoption of IFRS tends to be less disputed than that caused by mandatory adoption. It is widely accepted that in terms of amount and the quality of disclosures in financial statements, IFRS are found to supersede many other domestic financial reporting standards. In terms of cost of capital impact of IFRS adoption, the opinions are mixed and the divide is wider. Though the present study has not much focused on literatures in relation to IFRS' effect on cost of capital, it reasonably obtains from this review that IFRS' impact on the reduction of cost of capital depends on financial reporting incentives, law enforcement, types of legal systems and various other country and capital market specific characteristics. Further, though there are some evidences to the contrary, quality of earnings reported under IFRS has been established to be superior to that under other local standards as the IFRS are claimed to be more principle based thereby permitting more professional judgement that may not be possible under the rule based systems. In relation to comparative financial performance and position, the IFRS literatures report significant differences between pre and post IFRS adoption periods. Researches in this perspective focus on the changes, between pre and post IFRS adoption periods, in the amounts of deferred taxes, pensions, property, plant and equipment, goodwill, provisions for loss, total assets, book value of equity, net income and such common financial statement ratios as asset turnover ratio, debt-to-asset ratio and liquidity measures. 


\section{REFERENCES}

[1] E. Lee, M. Walker, H.B. Christensen, Mandating IFRS: its impact on the cost of equity capital in Europe, No. RR105, ACCA, Manchester, 2008.

[2] G. Iatridis, International Financial Reporting Standards and the Quality of Financial Statement Information, International Review of Financial Analysis. 19 (2010)193-204.

[3] F. Tsoligkas, I. Tsalavoutas, Value relevance of R\&D in the UK after IFRS mandatory implementation, Applied Financial Economic. 21 (13) (2011) 957-967

[4] E.K. Jermakowicz, J. Prather-Kinsey, I. Wulf, The value relevance of accounting income reported by DAX-30 German companies, Journal of International Financial Management and Accounting. 18(3) (2007) 151-91.

[5] S. Callao, J.I. Jarne, J.A. Laínez, Adoption of IFRS in Spain: effect on the comparability and relevance of financial reporting, Journal of International Accounting, Auditing and Taxation. 16 (2007) 148-178.

[6] L.A. Beisland, K.H. Knivsfla, Have IFRS changed how stock prices are associated with earnings and book values?, Review of Accounting and Finance.14(1) (2015) 41 - 63.

[7] C.I. Negakis, The explanatory power of earnings for stock returns in the pre- and post-IFRS era, Managerial Finance. 39(9) (2013) 814 - 824.

[8] N. Karampinis, D. Hevas, The Effect of the Mandatory Application of IFRS on the Value Relevance of Accounting Data: Some Evidence from Greece, European Research Studies. 12 (1) (2009).

[9] G. Iatridis, S. Rouvolis,. The Post-Adoption Effects of the Implementation of International Financial Reporting Standards in Greece, Journal of International Accounting, Auditing and Taxation. 19 (2010)55-65.

[10] A.A. Ballas, D. Hevas, D. Neil, The state of accounting and the state of the state, Journal of Management and Governance. 2( 2) (1998) 267-85.

[11] N.I. Karampinis, D.L. Hevas, Mandating IFRS in an unfavorable environment: The Greek experience, The International Journal of Accounting. 46 (2011)304-332.

[12] K. Papadatos, A. Bellas,. The value relevance of accounting information under Greek and International Financial Reporting Standards: the influence of firm-specific characteristics, International Research Journal of Finance and Economics.76 (2011) 6-23.

[13] D. Dobija, K.M. Klimczak, Development of Accounting in Poland: Market Efficiency and the Value Relevance of Reported Earnings, The International Journal of Accounting. 45 (2010) 356374. Available at SSRNhttp://papers.ssrn.com/sol3/papers.cfm?abstract_id=1084423 (accessed 04 May 2015).

[14] B. Kirkulak, C.K. Balsari, Value relevance of inflation-adjusted equity and income, The International Journal of Accounting. 44 (2009) 363-377.

[15] A.Türel, The value relevance of IFRS: the case of Turkey, ActaUniversitatisDanubius, Economica. 5(1) (2009)119-128.

[16] S. Kargin, The impact of IFRS on the value relevance of accounting information: evidence from Turkish firms, International Journal of Economics and Finance.5(4) (2013).

[17] J.A. Ohlson, Earnings, book values, and dividends in equity valuation, Contemporary Accounting Research. 11(2) (1995) 661-87.

[18] Xu-D. Ji, W.Lu, The value relevance and reliability of intangible assets, Asian Review of Accounting. 22(3) (2014) $182-216$. 
[19] J.B. Khanagha, Value Relevance of Accounting Information in the United Arab Emirates, International Journal of Economics and Financial Issues. 1(2) (2011) 33-45.

[20] M.A. El-Shamy, M.Al-Hajri, S.Al Bassam, The value relevance of unrealized gains and losses recognized under IAS 39: evidence from Kuwait, International Journal of Commerce and Management. 24 (4) (2014).

[21] H.M. Nijam, IFRS Adoption and Value Relevance of Accounting Information: Evidence from Sri Lanka, (Unpublished MBA Thesis), Faculty of Management and Commerce, South Eastern University of Sri Lanka, Oluvil.

[22] B. Bao, L. Chow, The usefulness of earnings and book value for equity valuation in emerging capital market: evidence from listed companies in the People's Republic of Chin, Journal of International Financial Management and Accounting. 10 (1999) 85-104.

[23] E. Eccher, P.M. Healy, The role of international accounting standards in transitional economies: a study of the People's Republic of China, SSRN. (2000). Retrieved from: http://papers.ssrn.com/sol3/papers.cfm?abstract_id=233598(accessed 04 May 2015).

[24] D. Hu, The usefulness of financial statements under Chinese GAAP vs IAS: evidence from Shanghai Stock Exchange in PRC.working paper, Kobe University, Kobe (2002).

[25] H, Sami, H. Zhou, A comparison of value relevance of accounting information in different segments of the Chinese stock market, The International Journal of Accounting. 39(4) (2004) 40327.

[26] J. Liu, C. Liu, Value relevance of accounting information in different stock market segments: the case of Chinese A-, B-, and H-shares, Journal of International Accounting Research. 6 (2) (2007) 55-81.

[27] K. Chalmers, F. Navissi, W.Qu, Value relevance of accounting information in China pre- and post-2001 accounting reforms, Managerial Auditing Journal. 25(8) (2010) 792-813.

[28] E. Chamisa, M. Mangena, G. Ye, Relative value-relevance of accounting measures based on Chinese Accounting Standards and International Financial Reporting Standards, Journal of Accounting in Emerging Economies. 2(2) (2012) 162 - 187.

[29] M.H. Kadri, R.A. Aziz, M.K. Ibrahim, Value relevance of book value and earnings:evidence from two different financial reporting regimes, Journal of Financial Reporting and Accounting. 7(1) (2009) 1 - 16.

[30] S. Van der Meulen, A.Gaeremynck, M.Willekens, Attribute differences between U.S. GAAP and IFRS earnings: an exploratory study, The International Journal of Accounting. 42(2) (2007) 123-142.

[31] M. Verleun, G.Georgakopoulos, I.Sotiropoulos, K. Z.Vasileiou, The Sarbanes-Oxley Act and sccountingquality: acomprehensive examination, International Journal of Economics and Finance. 3(5) (2011) 49-64.

[32] A.O. Umoren, E.R. Enang,. IFRS Adoption and Value Relevance of Financial Statements of Nigerian Listed Banks, International Journal of Finance and Accounting. 4(1) (2015) 1-7.

[33] H. Daske, G. Gu"nther, International financial reporting standards and experts perceptions of disclosure quality, Abacus. 42(3/4) (2006) 461-98.

[34] I. Tsalavoutas, D.Dionysiou, Value relevance of IFRS mandatory disclosure requirements, Journal of Applied Accounting Research. 15(1) (2014) 22 - 42.

[35] G.H. Mardini, L.Crawford, D.M.Power, The impact of IFRS 8 on disclosure practices of Jordanian listed companies, Journal of Accounting in Emerging Economies, 2(1) (2012) 67 - 90. 
[36] F.Bova, R.Pereira, The determinants and consequences of heterogeneous IFRS compliance levels following mandatory IFRS adoption: evidence from a developing country, Journal of International Accounting Research. 11(1) (2012) 83-111.

[37] M. Macías, F. Muiño, Examining dual accounting systems in Europe, The International Journal of Accounting. 46(2011) 51-78.

[38] H. Daske, L. Hail, C.Leuz, R. Verdi, Mandatory IFRS reporting around the world: early evidence on the economic consequences, Journal of Accounting Research. 46(5) (2008)1085-1142.

[39] F. Han, H. He, Cost of equity capital of foreign firms, Review of Accounting and Finance. 12 (3) (2013) $268-285$

[40] N. Lambertides, K. Mazouz, Stock price volatility and informational efficiency following the mandatory adoption of IFRS in Europe, Journal of Applied Accounting Research. 14(1) (2013) 4 17.

[41] I. Goncharov, J. Zimmermann, Do accounting standards influence the level of earnings management? Evidence from Germany, Available at SSRN (2006). Retrieved from http://papers.ssrn.com/sol3/papers.cfm?abstract_id=386521( accessed on May 03 2015)

[42] M.E. Barth, W.R Landsman, M.H. Lang, International accounting standards and accounting quality, Journal of Accounting Research. 46(3) (2008) 467-98.

[43] T. Jeanjean, H. Stolowy, Do accounting standards matter? An exploratory analysis of earnings management before and after IFRS adoption, Journal of Accounting and Public Policy. 27(2008) 480-94.

[44] L.C.Doukakis, The persistence of earnings and earnings components after the adoption of IFRS, Managerial Finance. 36(11) (2010) 969 - 980.

[45] C.S. Cheong, S. Kim, R. Zurbruegg, The impact of IFRS on financial analysts' forecast accuracy in the Asia-Pacific region- The case of Australia, Hong Kong and New Zealand, Pacific Accounting Review. 22(2) (2010) 124-146.

[46] K. Chalmers, G. Clinch, J.M. Godfrey, Adoption of international financial reporting standards: impact on the value relevance of intangible assets, Australian Accounting Review. 18(4) (2008) 237-247.

[47] W.A.W Ismail, K.A. Kamarudin, T. Zij1, K.Dunstan,.Earnings quality and the adoption of IFRS-based accounting standards, Asian Review of Accounting. 21(1) (2013) 53 -73.

[48] F. Aubert, G. Grudnitski, Analysts' estimates What they could be telling us about the impact of IFRS on earnings manipulation in Europe, Review of Accounting and Finance. Vol. 11 (1) (2012)53- 72 .

[49] M. Hung, K.R. Subramanyam,.Financial statement effects of adopting international accounting standards: the case of Germany, Review of Accounting Studies. 12(4) (2007) 623-57.

[50] E.K. Jermakowicz, Effects of adoption of international financial reporting standards in Belgium: the evidence from BEL-20 companies, Accounting in Europe. 1(1) (2004) 51-70.

[51] M. Cordazzo, The impact of IFRS on net income and equity: evidence from Italian listed companies, Journal of Applied Accounting Research. 14(1) (2013) 54 - 73.

[52] L. Bayerlein, O. Al Farooque, Influence of a mandatory IFRS adoption on accounting practice, Asian Review of Accounting. 20(2) (2012) $93-118$.

[53] W. Stent, M. Bradbury, J. Hooks,. IFRS in New Zealand: effects on financial statements and ratios, Pacific Accounting Review. 22(2) (2010) 92 - 107. 
[54] D. Bao, J. Lee, G. Romeo, Comparisons on selected ratios between IFRS and US GAAP companies, Journal of Financial Reporting and Accounting. Vol. 8 (1) (2010) 22 - 34

[55] S. Fifield, G. Finningham, F .Fox, D. Power, M. Veneziani, A cross country analysis of IFRS reconciliation statements, Journal of Applied Accounting Research. Vol. 12 (1) (2011) $26-42$

[56] G. Iatridis, K. Dalla, The impact of IFRS implementation on Greek listed companies: An industrial sector and stock market index analysis, International Journal of Managerial Finance. 7(3) (2011) $284-303$. 